Winner of the Collins Religious Book Prize for 1977 Paperback edition

\title{
The Origin of Christology
}

\section{F. D. MOULE}

'This book is of the utmost importance for the study of the early days of the Christian church.'

The Daily Telegraph

'... a book to be patiently taken... by those who are prepared to work towards remedying the ills of Christian theology. It must be admitted that there are precious few remedies as thorough and as available as this.'

The Month

Paperback $\$ 2.75$ net

Paperback edition

\section{Christ, Faith and History}

Cambridge Studies in Christology

Edited by S. W. SYKES and J. P. CLAYTON

'The most important collection of theological essays to appear in England for a long time. The issues raised are many and varied, but seldom does one feel that they are of less than major importance.' Modern Churchman

Contributors: M. F. Wiles, Peter R. Baelz, John A. T. Robinson, S. W. Sykes, Sebastian Moore, C. F. D. Moule, G. W. H. Lampe, Don Cupitt, J. P. Clayton, P. F. Carnley, G. N. Stanton, J. C. O’Neill, J. K. Riches, Steven T. Katz, B. L. Hebblethwaite, D. M. MacKinnon.

Paperback $£ 3.95$ net

\section{SOCIETY FOR NEW TESTAMENT STUDIES MONOGRAPHS 32 On the Independence of Matthew and Mark}

\section{J. M. RIST}

Professor Rist challenges the general assumption that the relationship between our canonical texts of the Gospels of Matthew and Mark is to be explained in terms of direct literary dependence either of Matthew on Mark or vice versa. He argues that Matthew and Mark grew up independently on the basis of a common oral tradition, and supports his view by detailed examination of a large number of parallel passages.

$£ 5 \cdot 30$ net

\section{SOCIETY FOR NEW TESTAMENT STUDIES MONOGRAPHS 33 Redactional Style in the Marcan Gospel}

\section{E. J. PRYKE}

Dr Pryke tests some 18 syntactically unusual features of 'Marcan usage' to see if they are mainly source material or editorial material added by the evangelist to create a flowing narrative. His conclusions will be of great value to those concerned with the analysis of St Mark's Gospel.

£10.00 net

\section{CAMBRIDGE UNIVERSITY PRESS}




\title{
NEW TESTAMENT STUDIES
}

AN INTERNATIONAL JOURNAL PUBLISHED QUARTERLY UNDER

THE AUSPIGES OF

STUDIORUM NOVI TESTAMENTI SOCIETAS

\author{
VOL. XXIV \\ I 978
}

\author{
EDITED BY \\ R. MCL. WILSON \\ ASSOGIATE EDITOR \\ M. E. THRALL
}

CAMBRIDGE UNIVERSITY PRESS

GAMBRIDGE $\cdot$ LONDON $\cdot$ NEW YORK

1978 


\section{PUBLISHED BY}

\section{THE SYNDICS OF THE CAMBRIDGE UNIVERSITY PRESS}

The Pitt Building, Trumpington Strect, Cambridge CB2 IRP

Bentley House, 200 Euston Road, London NWI 2DB

32 East 57th Street, New York N.Y. I0022

(C) Cambridge University Press 1978 


\section{CONTENTS}

'Si Monumentum Requiris, Circumspice'

ARTICLES

Professor W. D. Davies (Durham, N.C., U.S.A.). Presidential Address: Paul and the People of Israel

Rév. Père F. M. Braun, O.P. (Brussels, Belgium). La Réduction du Pluriel au Singulier dans l'Évangile et la Première Lettre de Jean

Professor Dr C. Burchard (Heidelberg, Germany/BRD). Joseph und Aseneth Neugriechisch

DR K. J. Thomas (Tehran, Iran). Torah Citations in the Synoptics

DR K. R. Snodgrass (Chicago, Ill., U.S.A.). I Peter ii. I-IO: its Formation and Literary Affinities

Rev. A. Feuillet (Paris, France). Le 'Commencement' de l'Économie Ghrétienne d'après $\mathrm{He}$ ii. 3-4; Mc i. I et Ac i. I-2

Dr James D. G. Dunn (Nottingham, England). Prophetic 'I'-Sayings and the Jesus tradition: The importance of testing prophetic utterances within early Christianity

Rev. W. R. G. Loader (Auckland, New Zealand). Christ at the right hand - Ps. cx. $I$ in the New Testament

Rev. Professor Carlo M. Martini (Rome, Italy). Is There a Late Alexandrian Text of the Gospels?

Professor Dr Georg Strecker (Bovenden, Germany). Eine Evangelienharmonie bei Justin und Pseudoklemens?

Drs Henk J. De Jonge (Leiden, The Netherlands). Sonship, Wisdom, Infancy: Luke ii. $4^{\mathrm{I}-5 \mathrm{I} a}$

Rev. Professor R. H. Fuller (Alexandria, Virginia, U.S.A.). Baur Versus Hilgenfeld: A Forgotten Chapter in the Debate on the Synoptic Problem

Professor Robert T. Fortna (Ploughkeepsie, New York, U.S.A.). Jesus and Peter at the High Priest's House: A Test Case for the Question of the Relation Between Mark's and John's Gospels

Professor Dr G. Bornkamm (Heidelberg, Germany). Presidential Address: Der Aufbau der Bergpredigt

Professor Dr Peiter Stuhlmacher (Tübingen, Germany). Adolf Schlatter's Interpretation of Scripture

Professor Étienne Trocmé (Strasbourg, France). Exégèse Scientifique et idéologie: de l'école de Tubingue aux Historiens Français des origines chrétiennes 
Dr Wilhelm Wuellner (Berkeley, California, U.S.A.). Toposforschung und Torahinterpretation bei Paulus und Jesus page 463

Professor J. Lambrecht (Heverlee, Belgium). The Line of Thought in Gal. 2. $1_{4} b-2$ I

Professor Dr A. BöHlig (Tübingen, Germany). Zur Struktur Gnostischen Denkens

Dr A. G. Thiselton (Sheffield, England). Realized Eschatology at Corinth

Dr David Hill (Sheffeld, England). On the Use and Meaning of Hosea vi. 6 in Matthew's Gospel

Dr W. J. Moulder (Deerfield, Ill., U.S.A.). The Old Testament Background and the Interpretation of Mark X. 45

Professor Max Wilcox (Bangor, Wales). The 'Prayer' of Jesus in John xi. $4 \mathrm{I}$ b-42

Dr M. E. Thrall (Bangor, Wales). The Problem of II Cor. vi. I4-vii.

I in some recent discussion

Rev. D. C. Parker (London, England). The Development of Textual Criticism since B. H. Streeter

Rev. Dr M. D. Goulder (Birmingham). On putting Q to the test 218

Rev. M. D. Goulder. Mark xvi. I-8 and Parallels

Professor Otfried Hofius (Salzkotten, Germany). Alttestamentliche Motive im Gleichnis vom verlorenen Sohn

M. Pierre Auffret (Nantes, France). Note sur la structure littéraire de Lc i. $68-79$

Professor Howard Clark Kee (Bryn Mawr, Pa., U.S.A.). The Ethical Dimensions of the Testaments of the XII as a Clue to Provenance

Dr Klaus Berger (Heidelberg, Germany). Zur Diskussion über die Herkunft von I Kor. ii. 9

Abbé Jean Carmignac (Paris, France). II Corinthiens iii. 6, i4 et le Début de la Formation du Nouveau Testament

Peter H. Davids (Pennsylvania, U.S.A.). The meaning of ámeipaotos in James i. I 3

Dr Dennis C. Duling (Ada, Ohio, U.S.A.). The Therapeutic Son of David: An Element in Matthew's Christological Apologetic

StANLEY K. Riegel (Lumphanan, Aberdeenshire, Scotland). Jewish Christianity: Definitions and Terminology

Professor Lou H. Silberman (Nashville, Tennessee, U.S.A.). Anent the Use of Rabbinic Material

Professor Paul Harlé. Un 'private-joke' de Paul dans le livre des Actes (xxvi. 28-29) 


\section{GONTENTS}

Professor Gordon D. Fee (South Hamilton, Massachusetts, U.S.A.). XAPI $\Sigma$ in II Corinthians i. I5: Apostolic Parousia and PaulCorinth Chronology page 533

Professor Sakae Kubo (Berrien Springs, Michigan, U.S.A.). I Corinthians vii. I6: Optimistic or Pessimistic?

Rev. Dr James M. Gibbs (Bangalore, South India). Canon Cuming's 'Service-Endings in the Epistles': A Rejoinder

REPoRt OF TÜBINGEN MEeting

MEMbe RSHIP LIST

Books RECEIVED 572

Index to Vol. 24 576 
C Cambridge University Press 1978

PRINTED IN GREAT BRITAIN AT THE UNIVERSITY PRESS, CAMBRIDGE 